\title{
THE GULF STREAM FRONT: A CAUSE OF STRATUS ON THE LOWER ATLANTIC COAST
}

\author{
ROBE B. CARSON \\ Weather Bureau Airport Station, Miami, Fla. \\ [Manuscript received March 13, 1950]
}

\begin{abstract}
Wintertime stratus along the lower Atlantic coast of the United States is discussed and the frontal hypothesis for its formation is stated. Evidence from sequences of weather charts is presented in support of the frontal interpretation.
\end{abstract}

\section{CONTENTS}

Introduction

Frontogenesis along the Gulf Stream

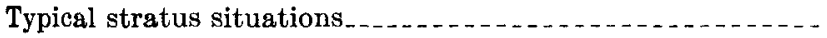

Situation of November 19-22, 1947 . . . . . . . .

Situation of December 12-14, 1947 . . . . . . . . . . .

Situation of December 22-23, 1947 . . . . . . . . . . .

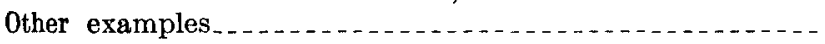

Acknowledgment . . . .

References

\section{INTRODUCTION}

A considerable portion of the lower Atlantic coast of the United States is subject to wintertime stratus of such intensity and persistence as to seriously hamper aircraft operations over heavily traveled routes. Because the very contrasts that cause residents of northern sections of the United States to fly to Florida are basic causes of this stratus, the peaks of worst weather and heaviest traffic often coincide. There has been disagreement in the analyses of this weather by various forecasters. It is a purpose of this paper to present the case for a frontal interpretation of it. This concept is not new; it originated in 1939 with J. J. George [1]. It is hoped that the discussion and evidence presented in this paper will stimulate a reconsideration of this problem and promote wider acceptance of its frontal solution.

$$
897386-50-1
$$

\section{FRONTOGENESIS ALONG THE GULF STREAM}

George [1] concluded that "pure advection fog at Jacksonville is almost strictly analogous in its method of formation to the stratus fogs of the California littoral". In Florida, however, the cap on convection is supplied by an actual warm front which forms offshore along that part of the coastline that is concave eastward. The southern limit of the stratus, approximately Vero Beach, Fla., but on rarer occasions nearer Miami, Fla., is indeed a region of the coast that could he described as a point of inflection, with the concavity turning to the west. The northern limit is between Charleston, S. C., and Cape Hatteras, N. C. ${ }^{1}$

The method of formation of what George terms the "northeast stratus" is as follows: A cold High centered in the eastern United States at a latitude generally north of $37^{\circ}$ causes a flow of cold air down the Atlantic Coastal Plain, with a pronounced wedge paralleling the coast east of the mountains. Because of the heating and resulting lowering of pressure over the ocean waters, the ridge is restricted to the region north and west of the Gulf Stream. Under these conditions, coastal isobars are commonly oriented northeast-southwest, with surface air crossing them in such a way as to move parallel to the axis of the

\footnotetext{
I A similar effect is often observed between Nantucket, Mass., and Ocean City, Md. where the same kind of coastline is found west of the Gulf Stream.
} 


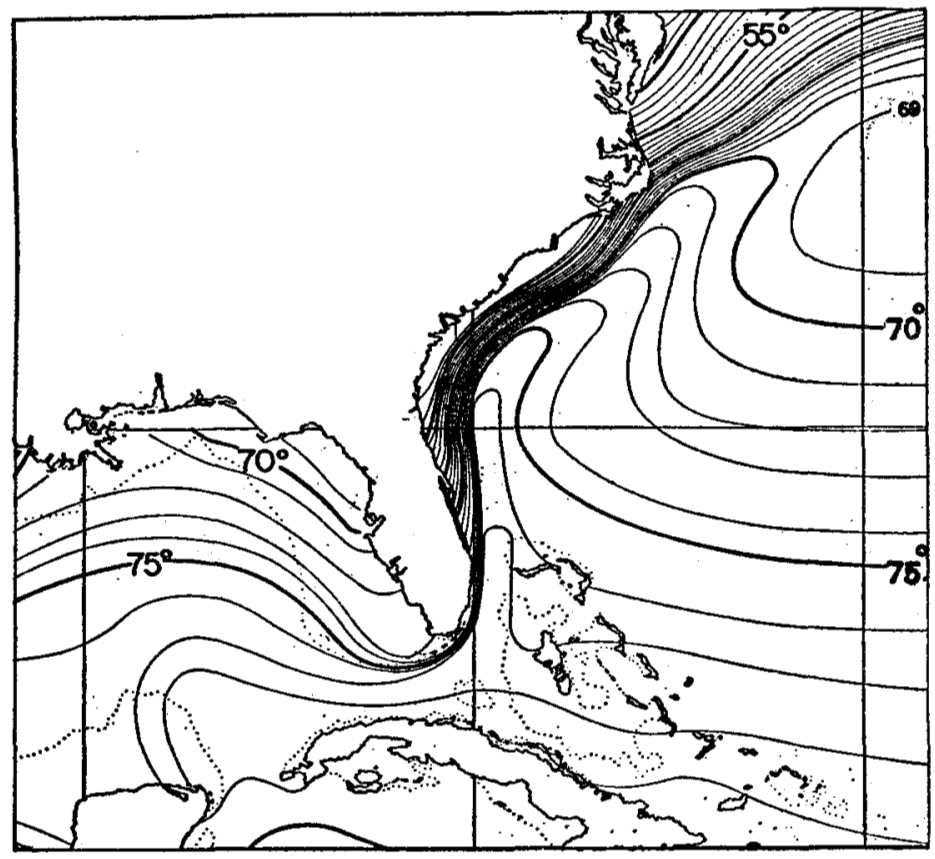

Figura 1.-A verage sea surface isotherms ( ${ }^{\circ}$ F.) for December. After Fuglister [2], by permission of Woods Hole Oceanographic Institution.

Gulf Stream and nearly parallel to the sea isotherms. (See fig. 1.) With the marked thermal differences during winter along this coast, adjacent portions of the polar air mass encounter vastly different conditions. The air over the central axis of the Gulf Stream is subjected to much heating. The warmed air is carried aloft where it is picked up by an easterly current that spreads it over Jacksonville, Fla., and points west at a level that is often at or even below 1,000 feet. It is probably because of this that the warm front is usually overlooked on winds aloft charts; the cold wedge is so shallow that the wind shifts are below standard levels. Typical soundings over Charleston, S. C., show air aloft that is $5^{\circ}$ to $15^{\circ} \mathrm{C}$. warmer than surface air, with the rapid increase of potential pseudo-wet-bulb temperature characteristic of a frontal rather than a subsidence inversion. Under such a pronounced, low frontal surface it is possible for a layer of stratus to build down to the ground simply as a result of evaporation from falling rain, since the entire layer of cold air is usually well below the temperature of the falling raindrops. However, there is very little precipitation associated with the Gulf Stream front; 6-hour amounts generally run less than .02 inch at the surface, and as the layer of easterly overrunning is typically rather thin it appears we must look elsewhere for the cause of the characteristic stratus. George found it in the trajectory of air leaving the coast at Charleston; these cold north-northeast surface winds pick up much heat and moisture from the short trip over relatively warm water surface, and convection is set up as the air becomes unstable. With an unusually low cap such as that described, these convection clouds quickly spread out in low levels, with a resulting stratus that blankets the coastal area between Charleston and St. Augustine, Fla. These 200- to 800-foot ceilings commonly spread to points as far away as Tampa and Tallahassee, Fla., and Atlanta, Ga., and they may persist for as long as a week.

A similar trajectory sometimes produces weather without the front. Watson [3], in discussing the effect of a northeasterly flow of air along this coast, mentions the effect of varying surface friction over land and water, with the air crossing the isobars at a sharper angle over Florida than over the Gulf Stream. This tends to produce a line of convergence along the coast between the northeasterly flow over the Atlantic and the more northerly flow over the coast and undoubtedly augments the action of the Gulf Stream in triggering many showers along the Florida east coast. George offered these showers as an aid in forecasting the northeast stratus; in the absence of soundings in critical parts of the coast where the necessary inversion first develops, these coastal showers can generally be used as evidence that the convective cap has not yet appeared. ${ }^{2}$

Miller [4], in an analysis of cyclogenesis in the Atlantic coastal region, also found frontogenesis occurring off the coast of Jacksonville, Fla. In his opinion the situation was better analyzed by a new front instead of representing the front as an extension of the warm front from an older primary cyclone. The experience of the writer confirms this belief, as ceilings west of the Gulf Stream front seem to go down quite independently (and often prior to the formation) of any wave in the Gulf. They are also consistently much lower than those near the wave.

\section{TYPICAL STRATUS SITUATIONS}

A meteorological picture of the wintertime stratus conditions is probably best presented by a sequence of weather charts. Maps and charts that follow were selected as typical of many situations noted by the author that clearly confirm the hypothesis of frontogenesis along the Gulf Stream.

SITUATION OF NOVEMBER 19-22, 1947

Figure 2, the 0730 EST synoptic surface chart for November 19, 1947, shows the usual beginning of the stratus situation. A polar High centered over Michigan was pushing the wedge down the coastal plain, as evidenced by the curved isobar near Greensboro, N. C. Already the uneven modification of the air north of the wave cyclone was evident, with a front beginning between the more modified and less modified parts of the polar air. The ship at latitude $32.2^{\circ} \mathrm{N}$. reported a temperature of $67^{\circ} \mathrm{F}$., an intense contrast with the $43^{\circ}$ at Wilmington, N.C. Cloud and wind contrasts complete the picture, with extensive stratiform clouds west of the new front and cumuliform clouds reported east of it. Although such cumulonimbus

2 This and many other valuable tips are found in his paper, which is an outstanding example of the fertile technique of analyzing in detail the "local effects" which are too often considered a minor problem. 
clouds would conventionally be ascribed to overrunning currents from the wave cyclone, this case is open to strong suspicion that the heating of the Gulf Stream produced intense enough convection on the modified polar air to break through the inversion from the wave, which was weakening rapidly. On the other hand, contrast between the ship and the coast was intensifying as fresh polar air was brought down continuously through the Carolinas, and the inversion associated with this contrast was also intensifying as the easterly surface air north of the wave cyclone was forced over the cold northerly current when it reached the coastal area.

Of particular interest in this figure is the 600 -foot ceiling reported at Orlando, immediately north of the cold front in Florida; why should the ceiling slope upward to 2,500 feet at Daytona Beach, Fla., and then back down to 200 feet at Jacksonville? This could be ignored if it were not so typical of conditions following an outbreak of polar air into Florida. The regular pattern of extremely low ceilings far to the north of the original cold front suggests that another front was involved. So, too, does a pilot report received by the Miami Flight Advisory Weather Service (FAWS) and entered on the original map reproduced in figure 2 ; the top of the overcast was reported at 1,500 feet over Jacksonville, Fla., 3,000 feet over Alma, Ga., 4,000 feet over Macon, Ga., and 4,500 feet over Atlanta, Ga. These values seem too systematic to be over-

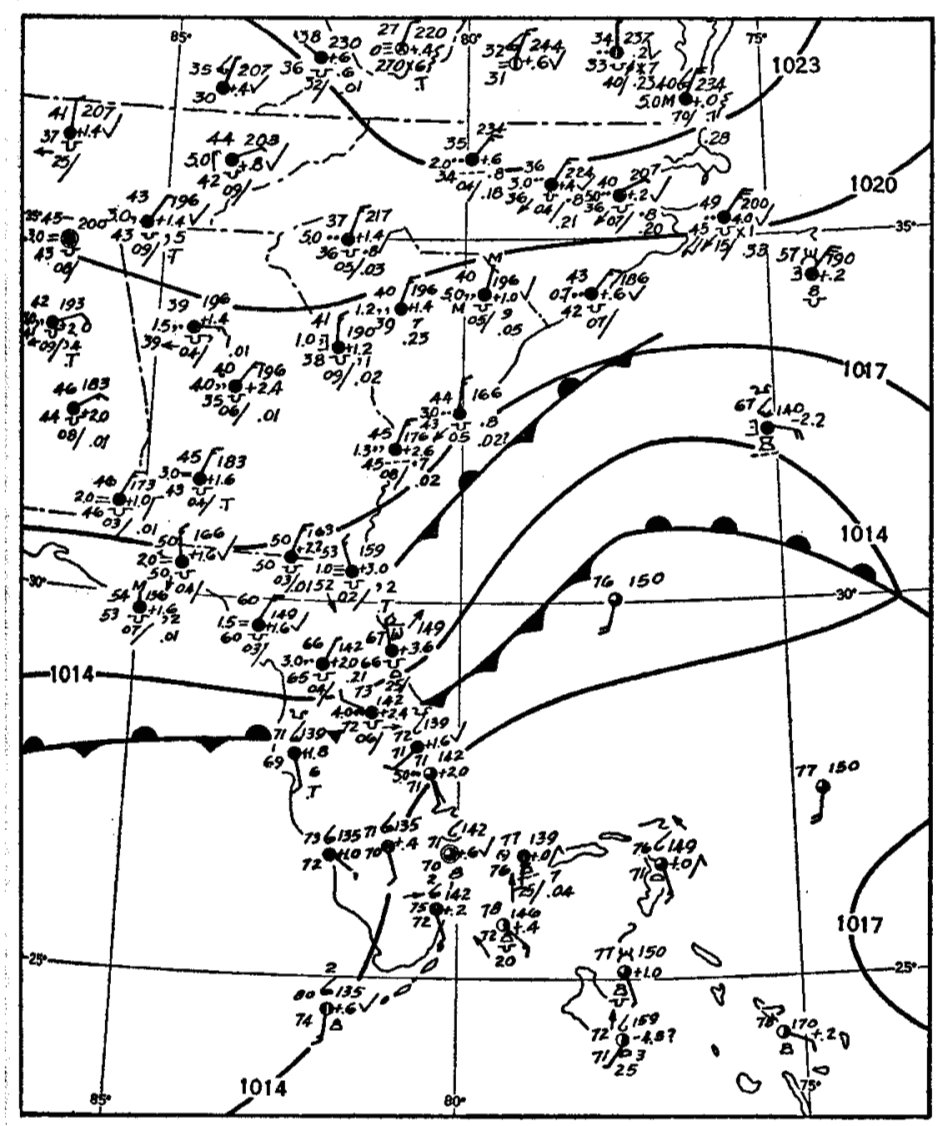

FIGURE 2.-Surface weather chart for 0730 EST, November 19, 1947. looked, and they suggest the slope of a cold wedge. They are plotted in figure 3 , where it will be noted that the extrapolated vertex of what seems to be a parabola strikes the surface about where the Gulf Stream front is drawn in figure 2.

Pilot reports in such situations often describe the ending of the stratus (or "sea fog") in this region. For example, Schroeder of AAT reported to the Miami FAWS Unit that on December 16, 1949, over Charleston, S. C., at 1600 EST, southbound at 6,000 feet, he observed

a wedge of stratus undercast beginning over the Gulf Stream and extending westward with tops generally 5000 MSL.

Farther east there were cumulus clouds with build-ups to 9000 MSL. The stratus line entered the coast at Melbourne where I filed IFR; however this was cancelled at West Palm Beach because the stratus did not extend that far south.

This was a situation in which the original cold front was already well into the Bahamas and Cuba.

By 1930 EST of November 19 (fig. 4) the older front was between West Palm Beach and Miami with temperature contrasts of less than $5^{\circ}$ per 100 miles. Yet a ship only 60 nautical miles from Wilmington, N. C., reported wind east-northeast, Beaufort force 5 , temperature $69^{\circ} \mathrm{F}$,

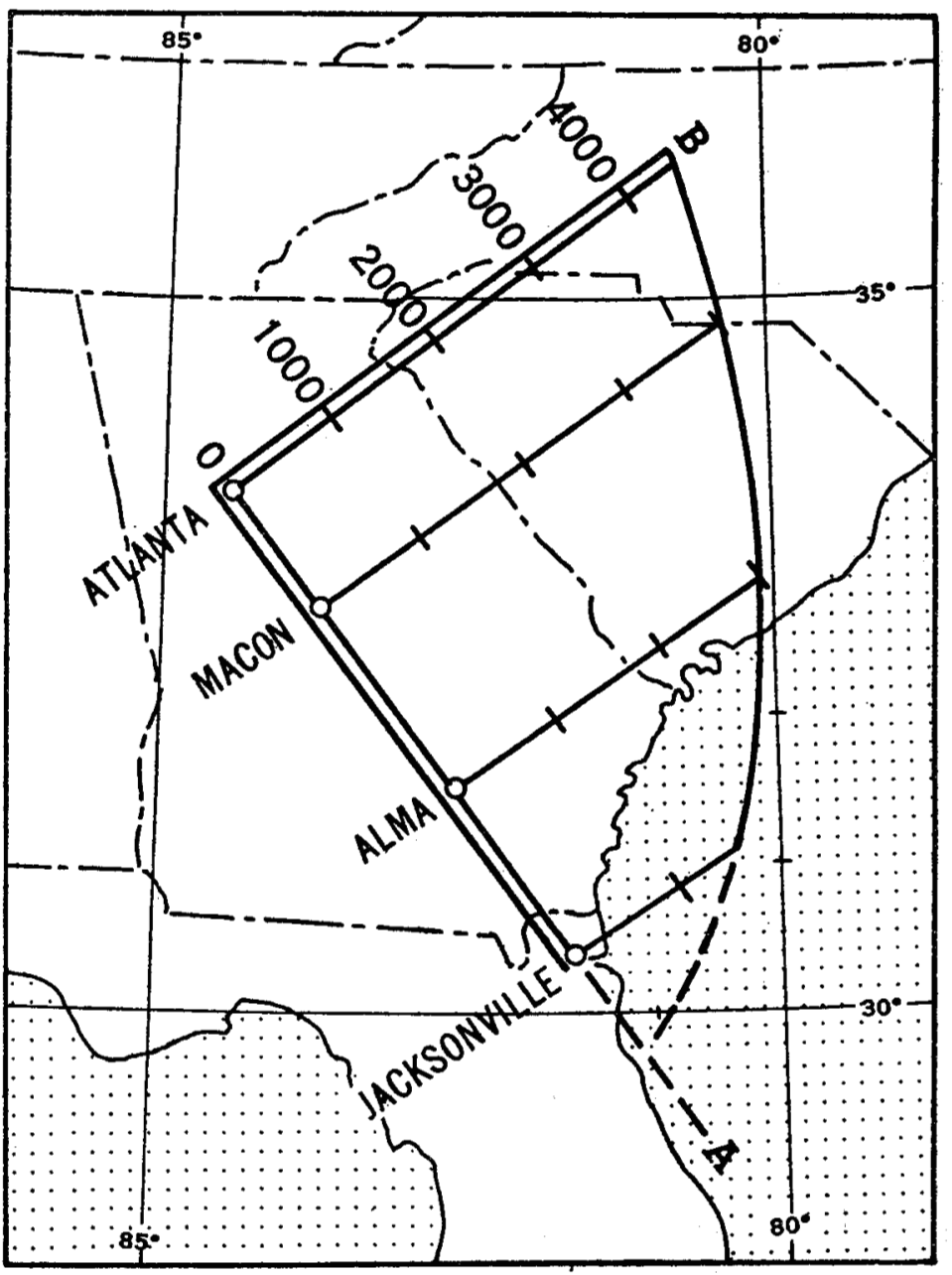

FlaURE 3.-Graph showing height (axis $O B$ ) of top of overeast along line $O A$ through Atlanta, Macon, and Alma, Ga., and Jacksonville, Fla 


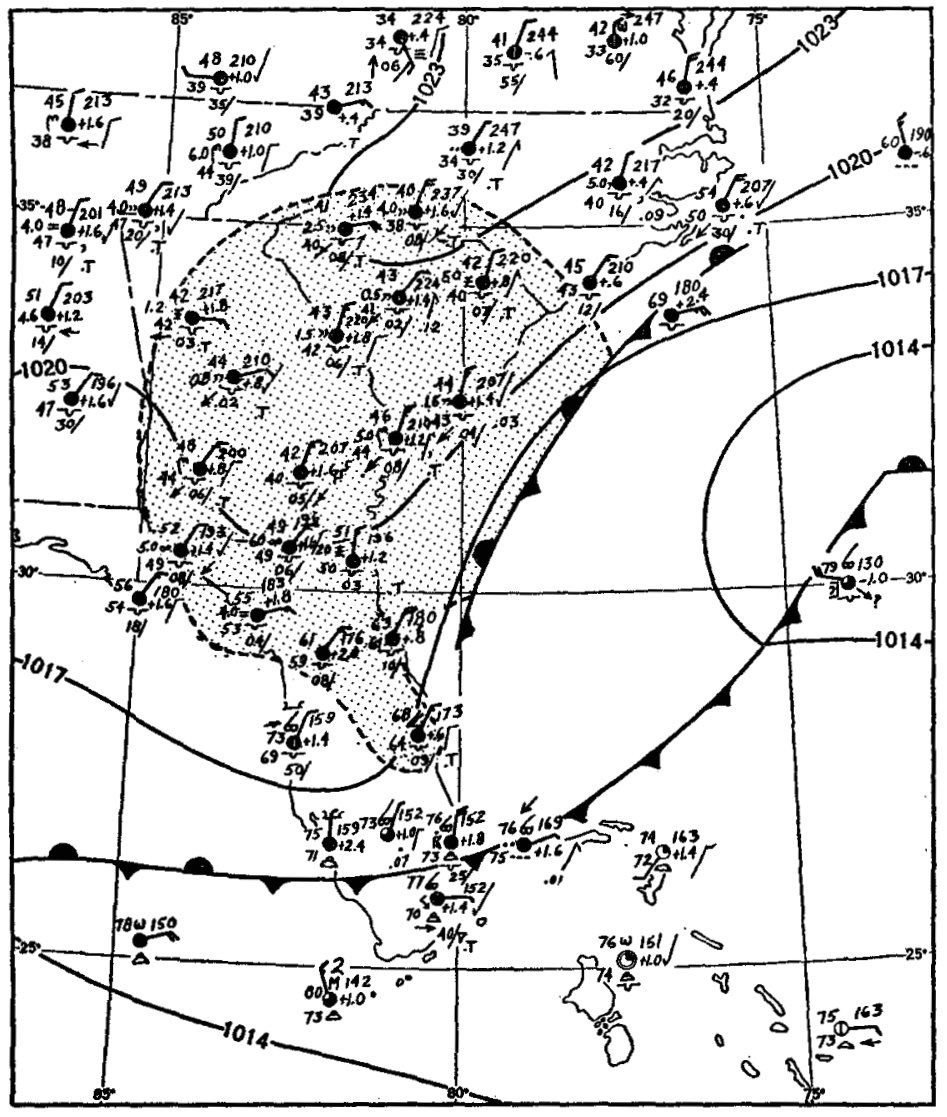

FIGURE 4.-Surface weather chart for 1930 EST, November 19, 1947. Shaded area indicates ceilings below 1,000 feet.

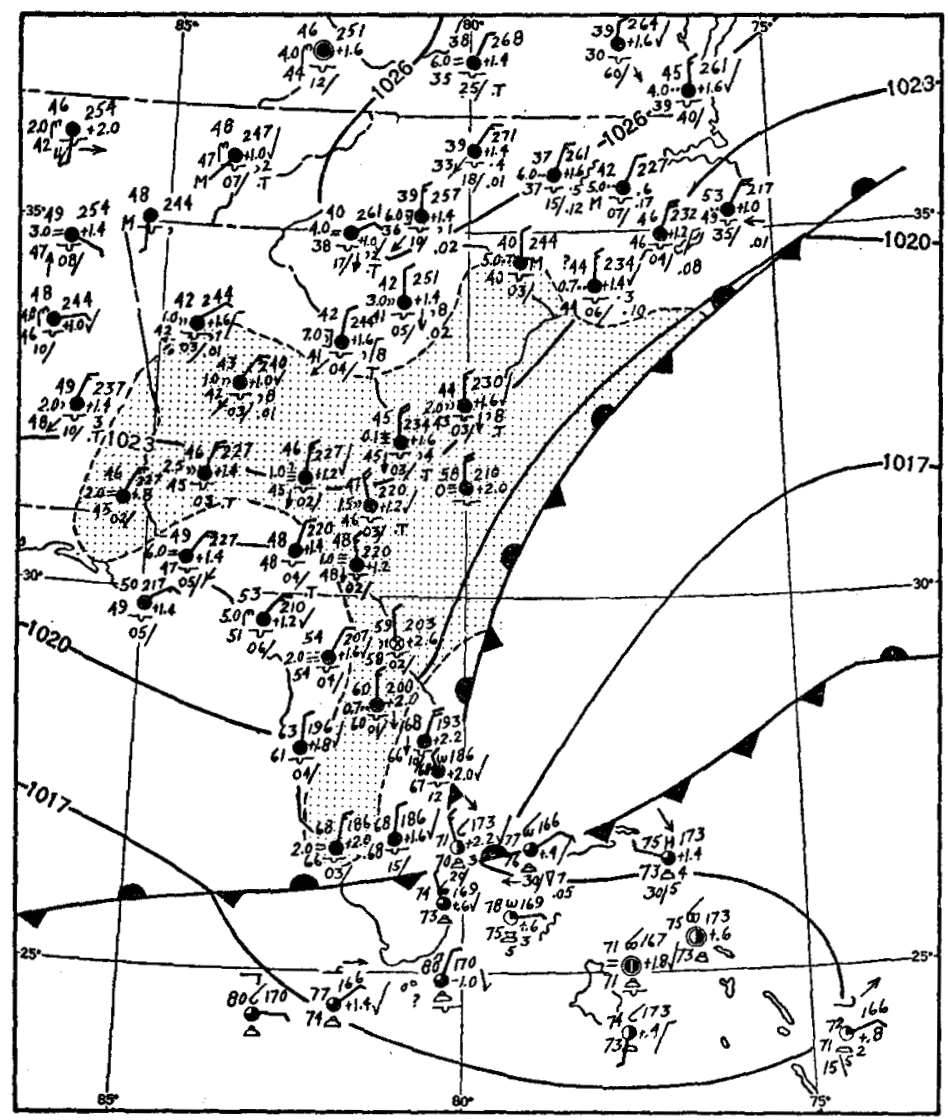

FIGURE 5.-Surface weather chart for 0730 EST, November 20, 1947. Shaded area indicates ceilings of 300 feet or lower. against Wilmington's northeast, force 3 , temperature $45^{\circ}$ F. This was a contrast of $24^{\circ}$ in less than 100 miles. Such sharp transitions are sometimes called "troughs" or overlooked entirely in frontal analyses. On this chart the ceilings below 1,000 feet are shaded to emphasize the separation of the stratus from the original front.

Figure 5 shows developments 12 hours later (0730 EST of the 20th). The shaded area here indicates ceilings of 300 feet or lower. Note the zero conditions reported by the ship south of Charleston, S. C.; this condition is usual on maps like this one. It is also common for ships a few degrees farther east to report fair or slightly showery weather. The lowest ceilings were centered in the Jacksonville, Fla. region, another common denominator of this oft-repeated wintertime situation. The persistence of the pattern separating the stratus from the original front showed that the stratus was not underrunning this front but rather underran a lower frontal surface that had formed entirely within the cold air. The tongue of low stratus reaching into Florida over Daytona Beach, Orlando, and Fort Meyers was oriented north-northeast to south-southwest, a perfect extension of the path that was

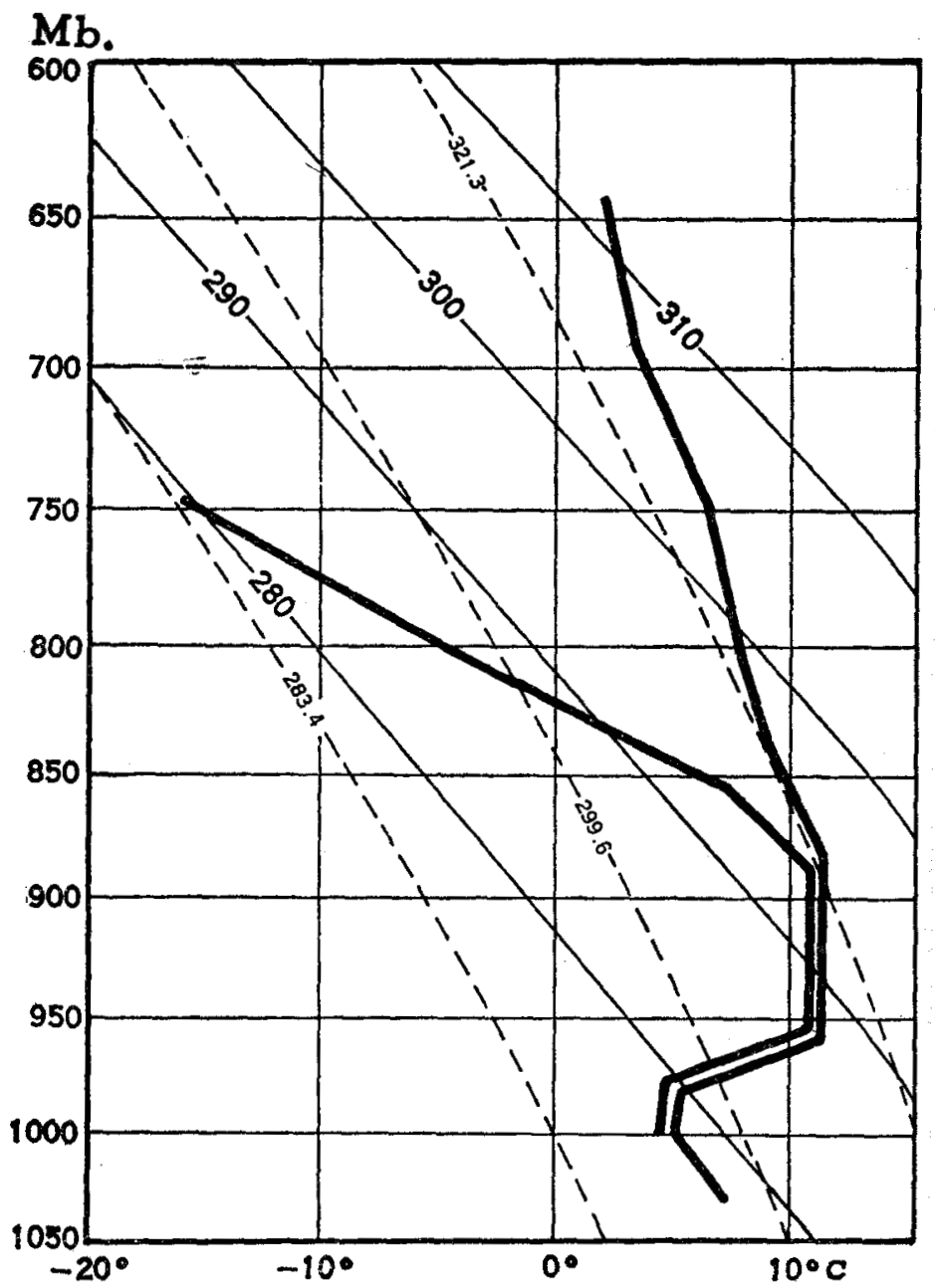

FIGURE 6.-Atmospheric sounding at Charleston, S. C., 1000 EST, November 20, 1947, plotted on pseudo-adiabatic chart. Plotted heavy solid lines are temperature (right) and potential pseudo-wet-bulb temperature (left). Light solid lines are dry adiabats and light broken lines are pseudoradiabats. 
taken by the air leaving the coast at Charleston. (See fig. 4.) It significantly avoided West PaIm Beach, Fla. because the air arriving here had not arrived under this low cap (note cumuliform clouds in both figs. 4 and 5).

The existence of the Gulf Stream front as drawn in figure 5 can be established in several ways. Note first the northerly direction of the stratus clouds in the cold air at Alma, Ga., and Charleston and Columbia, S. C., with the required easterly overrunning showing in higher level clouds at Cape Hatteras, N. C. And figure 6, the sounding for $1000 \mathrm{ES} T$ of the 20 th at Charleston, shows a frontal type inversion (less intense than is usually the case) between 1,000 and 1,500 feet. If this is taken as the beight of the front that crosses the coast at West Palm Beach, Fla., it becomes necessary to account for a slope of about 1 to 1400 , an exceptionally shallow wedge indeed. A more reasonable value of 1 to 200 locates the surface front about 60 miles off Charleston, where it is drawn in figure 5 .

The 1930 EST map for November 20 is given in figure 7. Here may be noted the persistence of 100 - to 400 -foot ceilings at Orlando, Daytona Beach, and Jacksonville, Fla., at a time of day when the diurnal rise had opened up most terminals elsewhere. The older front through Key West, Fla., was definitely of minor importance compared to the new front nearer Jacksonville where all the weather was. The Tampa, Fla., sounding taken a few hours after the time of this map is shown in figure 8 . Note the two inversions; the lower one was evidently the cap on the 600-foot stratus showing in figure 7.

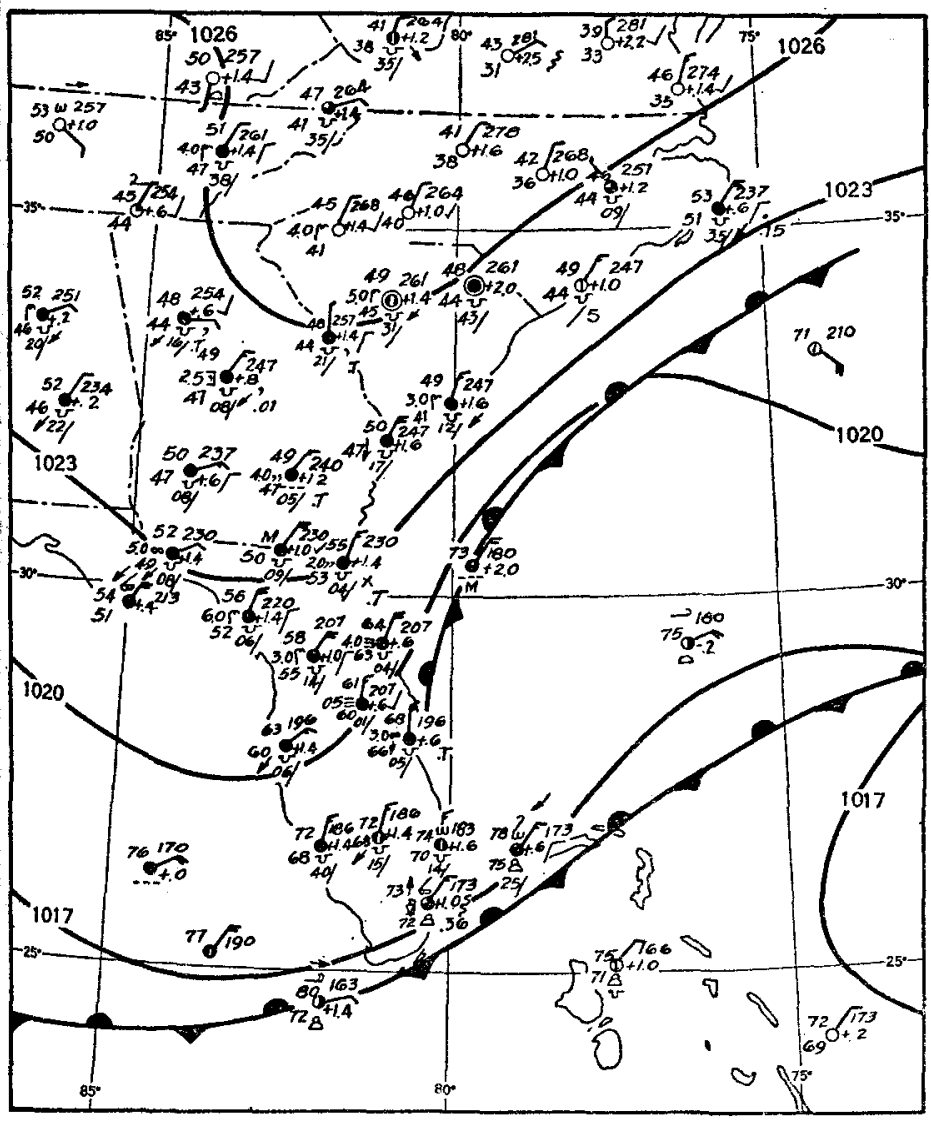

FIGURE 7.-Burface weather chart for 1930 EST, November 20, 1947.
By $0730 \mathrm{ES} T$ of the 22d numerous ship observations confirmed a well established front along the Gulf Stream as shown in figure 9. The $1100 \mathrm{EST}$ soundings at Charleston, S. C., and Apalachicola, Fla., (not reproduced) showed two frontal surfaces aloft, one in very low levels. By 1330 EST (fig. 10) the Gulf Stream front had moved inland. The surface circulation over eastern North Carolina shifted from northeast to southeast in the 6-hour period, with a temperature increase of 10 to 15 degrees. During the same period Greensboro, N. C., remaining in the cold air, went up only $1^{\circ}$. In figure 10 the relatively high ceilings over eastern North Carolina present considerable contrast to the 200 - to 400 -foot stratus blanketing the rest of the State, and any analysis that notes only the feeble front through Florida seems less than satisfying. The North Carolina contrasts on this chart are about as marked as any ever experienced in this area, and they were still in evidence 6 and 12 hours later along a line that extended to New York. Rapid frontolysis was, however, already assured as a consequence of the High shifting off the coast. Veering winds destroyed the peculiar set of coastal effects that had produced the front.

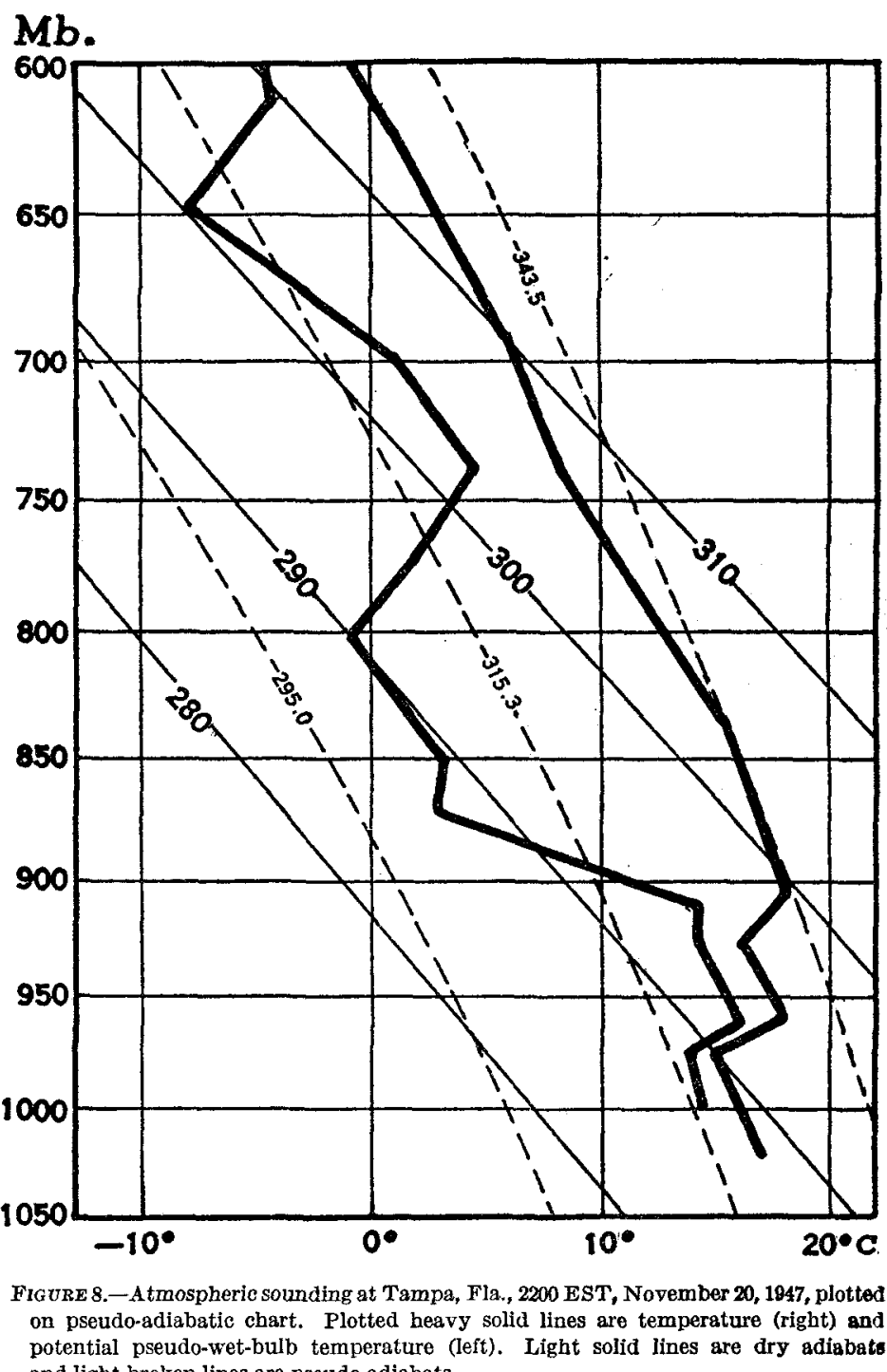
potential pseudo-wet-bulb temperature (left). Light solid lines are dry adiabat and light broken lines are pseudo-adiabats. 


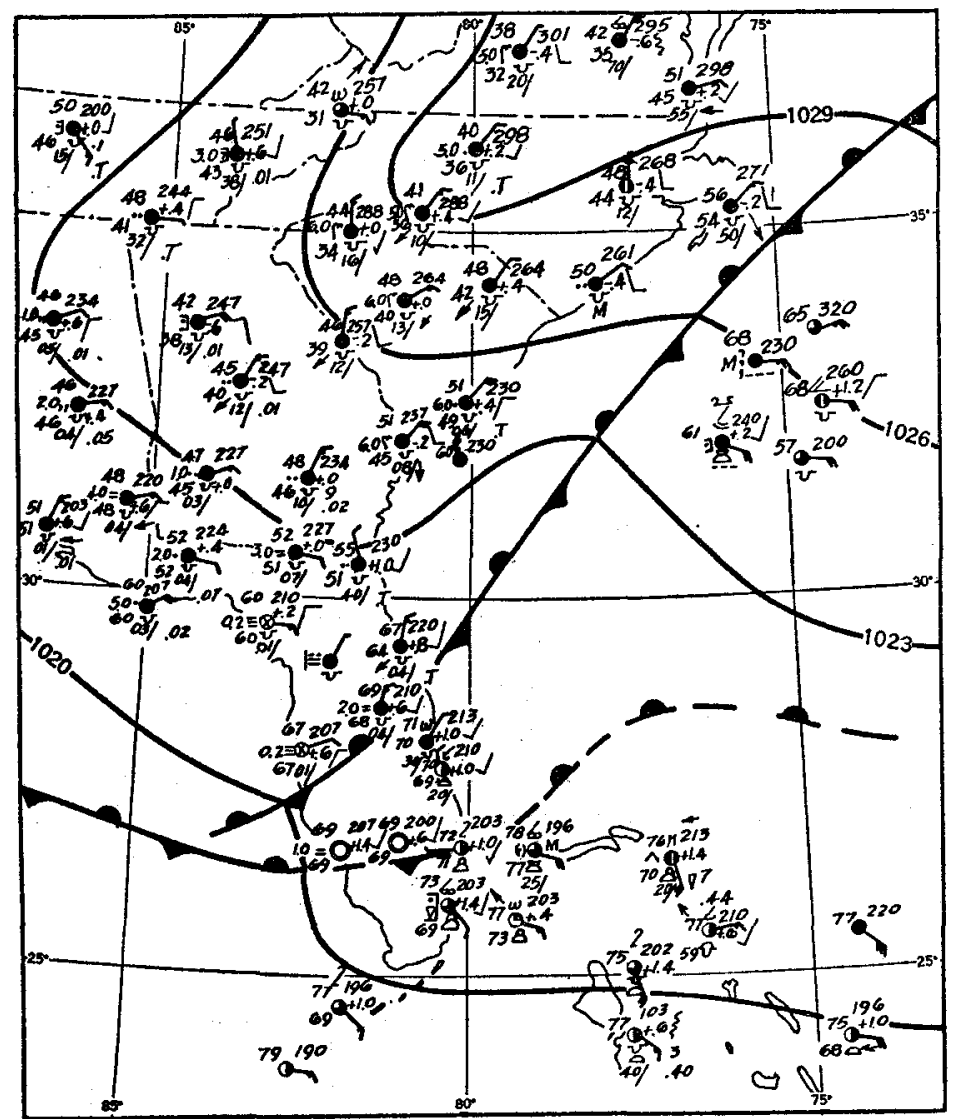

FIGURe 9.-Surface wasther chart for $0730 \mathrm{EST}$, November 22, 1947.

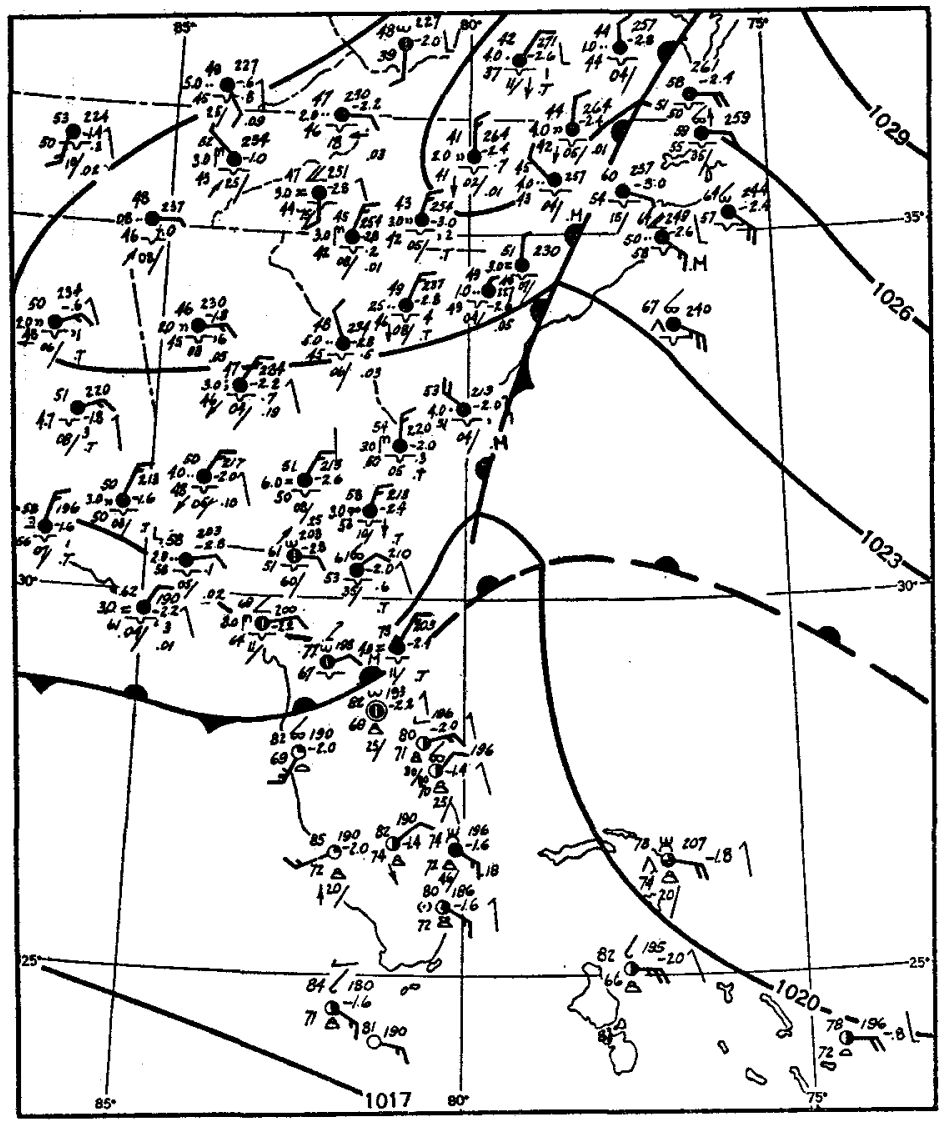

Figuri 10.--Surface weather chart for 1330 EST, November 22, 1947.
Such an invasion of the Carolina coast is sometimes accompanied by a wave formation that results in a new low. ${ }^{3}$ More often, however, the front not only produces no wave but fails to get ashore at all, as in the next example.

\section{SITUATION OF DECEMBER 12-14, 1947}

On December 12, 1947, at 0130 EST (fig. 11) a High was centered over Illinois, with the bare beginning of the wedge east of the mountains. The pattern was similar to that of figure 2, though in this case the region just north of the older front (Daytona Beach, Fla.) was actually clear while Jacksonville and most points north and west of it had stratus at 300 feet or lower. The ship report southeast of Wilmington, N. C., shows air that was $24^{\circ}$ warmer than the air at Wilmington. This was three times the contrast that appeared between this ship and the one much farther southeast in the tropical air, and is ample evidence that the main discontinuity had already developed within the polar air itself. The Charleston, S. C., sounding for 2200 EST of the 11th (not reproduced) showed warmer air beginning at or just below 1,000 feet, which is consistent with the Gulf Stream front as drawn.

Developments one day later are shown in figure 12. The effect of the warm Gulf Stream waters is evident in

For example, see surface weather chart for January 21, 1948, 0130 EST (not reproduced).

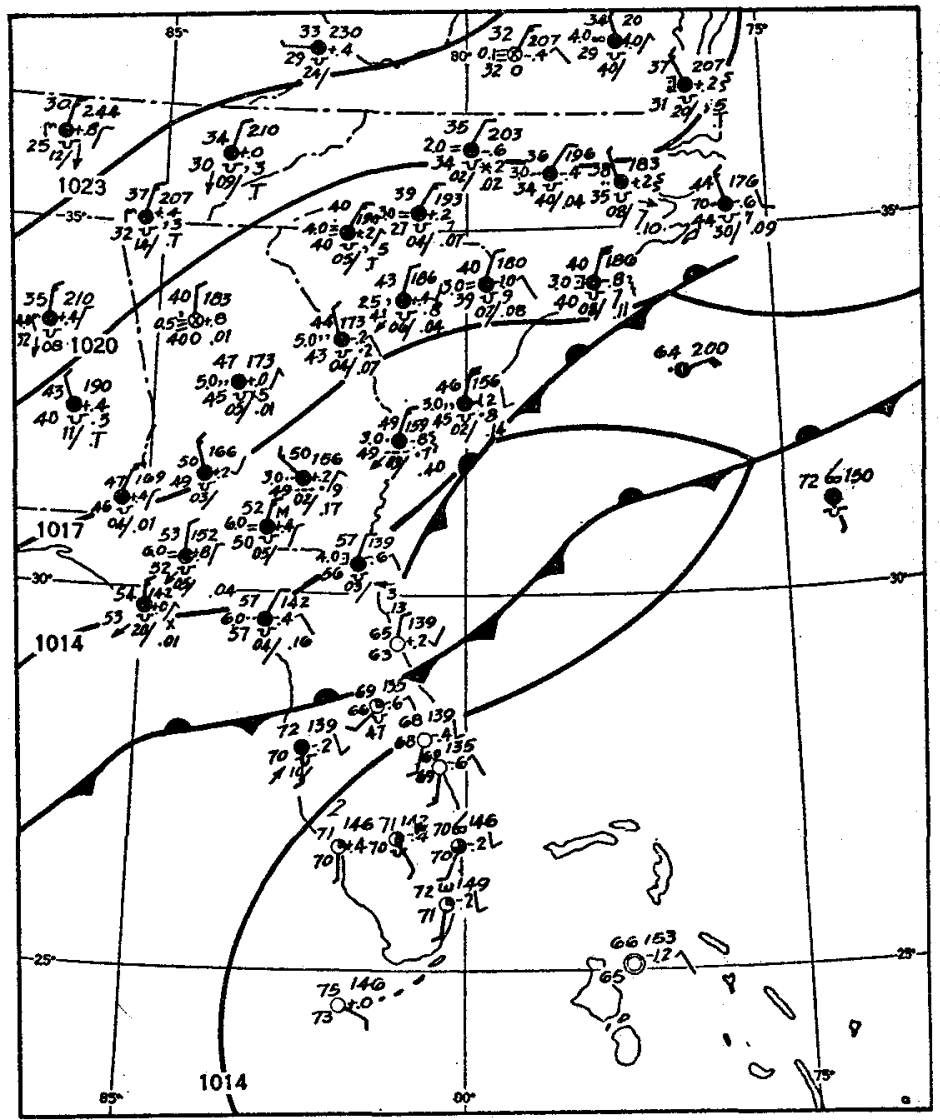

Figure 11.-Surface weather chart for 0130 E8T, December 12, 1947 
the wave off the east Florida coast. Although ship observations are inadequate in the Atlantic, it is not necessary to search far for evidence that the Gulf Stream front was still in existence. Figure 13, the Apalachicola, Fla, sounding for 2200 EST of December 12, shows two distinct frontal type inversions, one at 1,600 and the other at 4,800 feet. These correspond well with the fronts drawn in figure 12. The corresponding sounding for Charleston (not reproduced) also showed two fronts, with the older one about half again as high as the lower one. Figure 14 shows the corresponding Tampa, Fla., sounding with the expected single frontal surface. Figures $15 \mathrm{a}$ and $15 \mathrm{~b}$, showing winds aloft at 2,000 and 5,000 feet for $2200 \mathrm{EST}$, December 12, further confirm the existence of a front paralleling the coast. The windshift from northeast to westsouthwest between 200 and 500 feet at both Charleston, S. C., and Cape Hatteras, N. C., is striking.

The 5,000-foot west-southwest wind observed over Charleston appears to contradict the theory of the formation of the front, as this requires overrunning from the east, not the west. Figure 16 helps to clear this up. This 2200 EST sounding at Charleston for December 12, on which are plotted significant wind values, shows plainly that the real overrunning-that which produced the more intense inversion between 940 and $910 \mathrm{mb}$.- -was indeed from an easterly direction. The easterly current was, however, shallow and weakening as the westerlies took

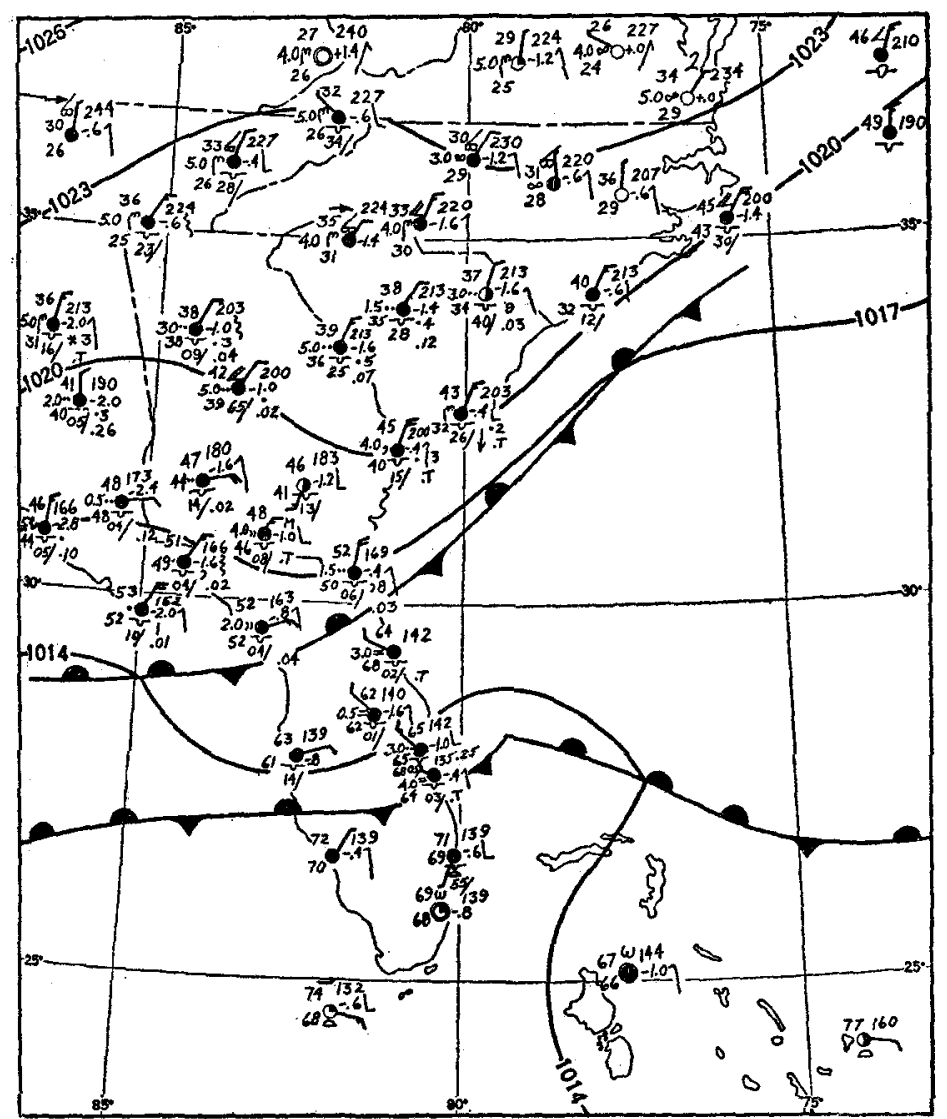

FIGURe 12.-Surface weather chart for 0130 EST, December 13, 1947. over at 4,000 feet and above. Perhaps this shallow easterly layer suggests already that the lower inversion was past its prime and would slowly diminish. It may also be noted that figure 16 too shows more than one frontal surface aloft. The notch between 860 and $850 \mathrm{mb}$. was likely introduced by a code error in taking the $850-\mathrm{mb}$. mandatory level, but the higher inversion was significant, although it appears to be partly of a subsidence type. The wet-bulb temperatures plotted between 775 and 660 $\mathrm{mb}$. indicate that a frontal surface, undoubtedly the original front, was between 750 and $600 \mathrm{mb}$.

Figure 17 (1330 EST of December 13) presents additional evidence of contrasts that satisfy most of the standard definitions of a front. Coastal temperatures in the thirties show a zero order discontinuity with ship temperatures in the sixties, and isallobars sketched in north Florida show a first order discontinuity with respect to pressure. Ceilings south of Brunswick, Ga., remained below 500 feet that night but showed signs of improvement during daylight hours of the 14th. By 1930 EST (fig. 18) they were down again although ceilings were spotty and were

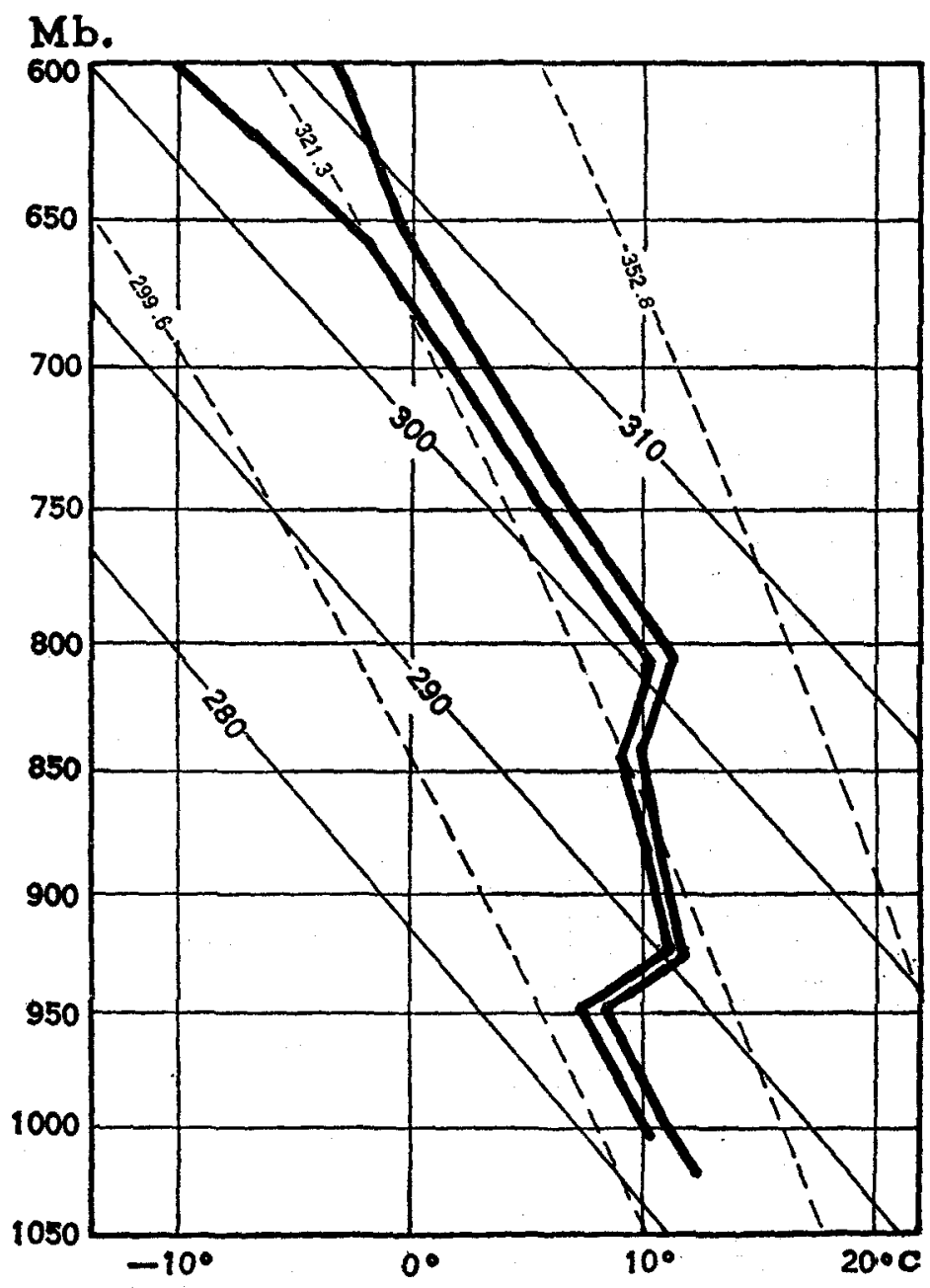

Froukn 13.-A tmospherio sounding at Apalachicola, Fla., 2200 EST, December 12, 1947. Plotted heary solid lines are temperature (right) and potential psendo-wet-bulb tem. perature (left). Light solid lines are dry adiabats and light broken lines are psendo. adiabats. 


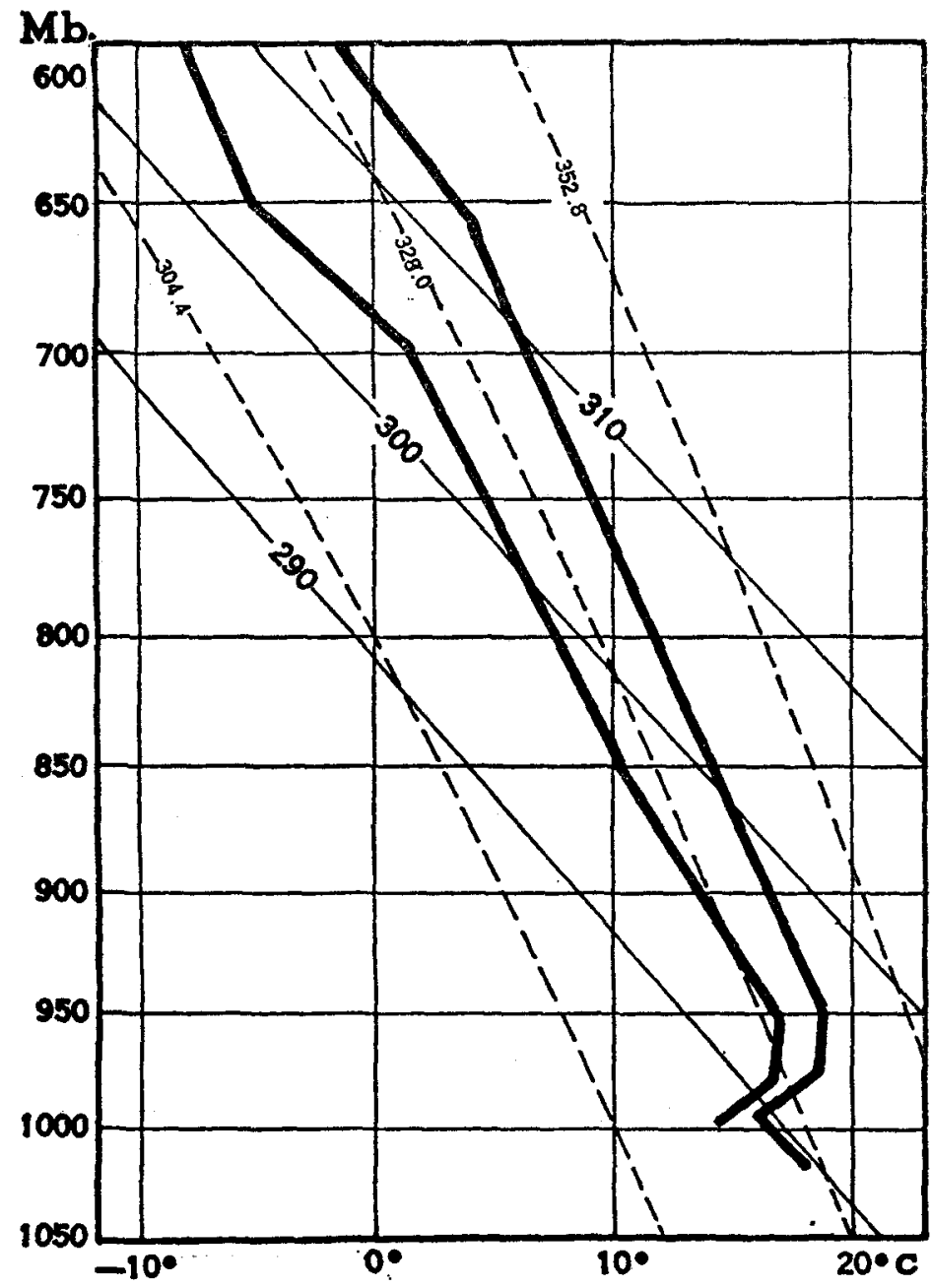

FIGURE 14.-Atmospheric sounding at Tampa, Fla., 2200 EST, December 12, 1947. Plotted heavy solid lines are temperature (right) and potential pseudo-wet-bulb temperature (left). Light solid lines are dry adiabats and light broken lines are pseudoadiabats.

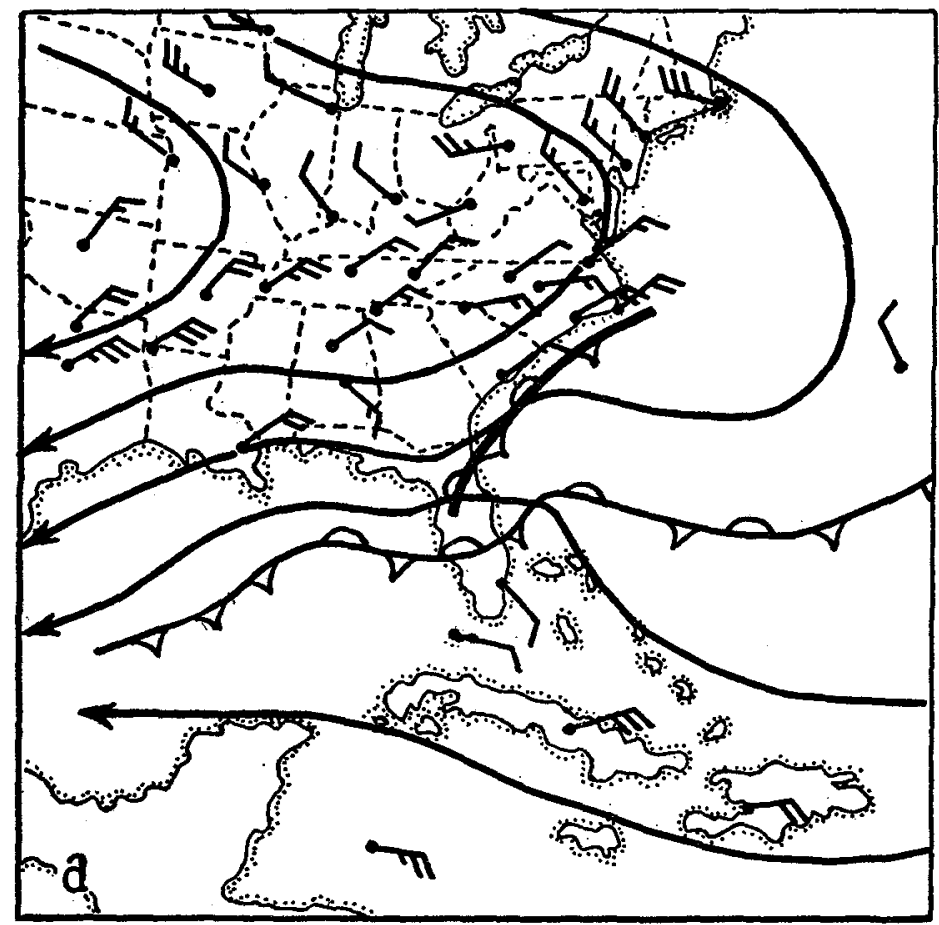

losing their systematic appearance. They were still below 500 feet on the middle east coast- -2 condition of much greater synoptic importance than the fine weather that surrounded the weakened older front through Miami. The Gulf Stream front was disintegrating, too; the High was moving off the coast near Ocean City, Md., and ceilings north of Jacksonville had lifted for good.

\section{SITUATION OF DECEMBER 22-23, 1947}

A final example was selected to illustrate the sometimes insidious, ephermeral nature of this front. It also shows the need for studies that might uncover methods for describing space and time limits of the phenomenon. The front sometimes barely forms and almost immediately disappears. It does not come from anywhere or usually go anywhere because it is not so much a product of dynamic pressure systems as of an exacting and particular set of local effects. Figure 19 shows surface conditions at 1330 EST, December 22, 1947, with the primary front safely out of the way and good weather over Florida. The experienced forecaster will be worried over such a map, though; the coastal wedge shows conditions shaping up for the northeast stratus. He cannot say just when or where it will form, though, except to point out the Jacksonville area as a likely spot. Six hours later, 1,200-foot ceilings appeared at Daytona Beach and Orlando, Fla. By 0130 EST of the 23d (fig. 20) zero conditions prevailed along the entire Florida east coast with the exception of the Miami region. At 0430 EST Miami entered the sequence with a 700 -foot overcast.

This condition-exceedingly rare at Miami-can be easily misinterpreted if the forecaster omits the Florida front from his analysis. An easterly 2,000-foot wind over

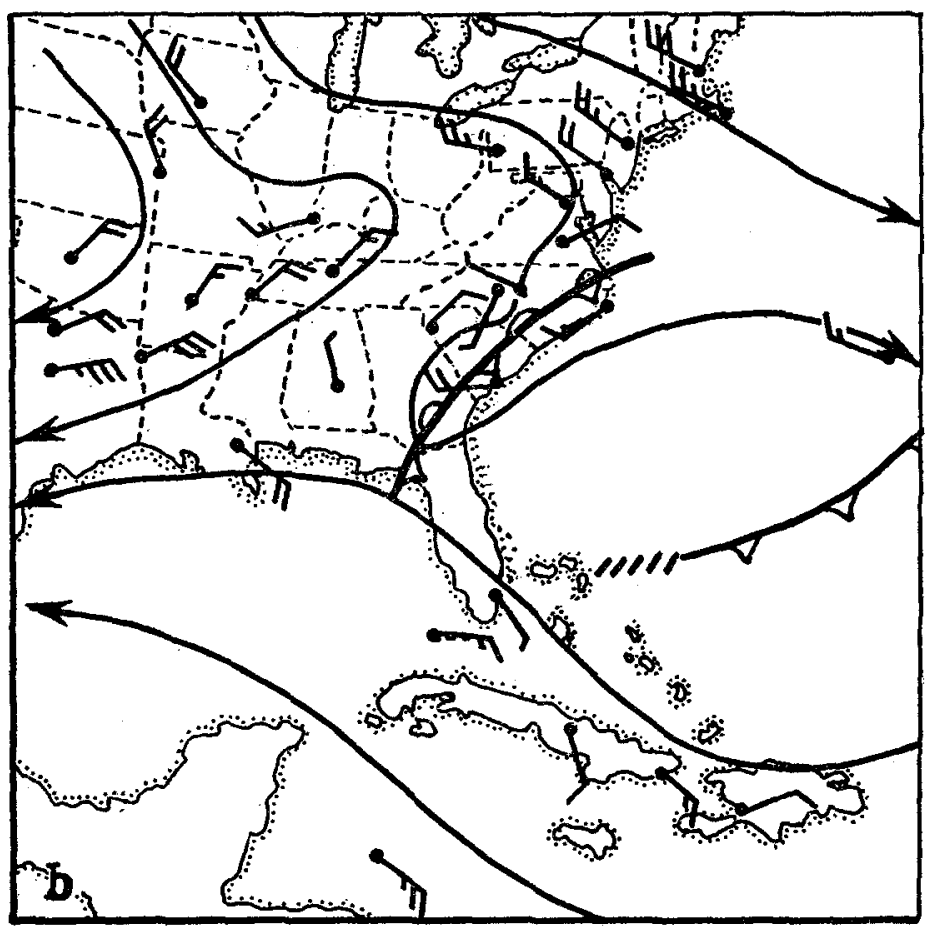

FIGURE 15.-Winds aloft and streamline charts for $2300 \mathrm{EST}$, December 12, 1947. (a) 2,000-foot winds. (b) 5,000-foot winds. 
Miami would then suggest rapid improvement after sunrise as is usually the case with ordinary ground fog. Actually the easterly flow here was vital to the formation of the stratus, and as long as it persisted above the shallow northerly flow it served to maintain the inversion that was holding the stratus to low levels in the polar air. The ceiling at Miami remained near zero most of the morning and below 1,000 feet most of the day. Figure 21 (0730 EST, December 23) shows the corrected analysis of the morning map.

Two pilot reports are of interest: Bretz of Zimel Airways, flying the Atlanta, Ga.,-Jacksonville, Fla.,-Tampa, Fla. route on the morning of the $23 \mathrm{~d}$, reported solid stratus, top over Jacksonville 1,200 feet, over Lakeland, Fla., 1,500 feet, over Tampa 1,000 feet, with the end of the stratus visible east of Jacksonville. McKusick of Air Carrier Operations said the stratus ended five miles east of Miami Beach, again in the Gulf Stream where the hypothesis of this paper demands that it terminate. Midday maps were not available due to circuit break-downs, but by night both the easterly circulation aloft and the shallow northerly surface flow had broken down and the front disintegrated.

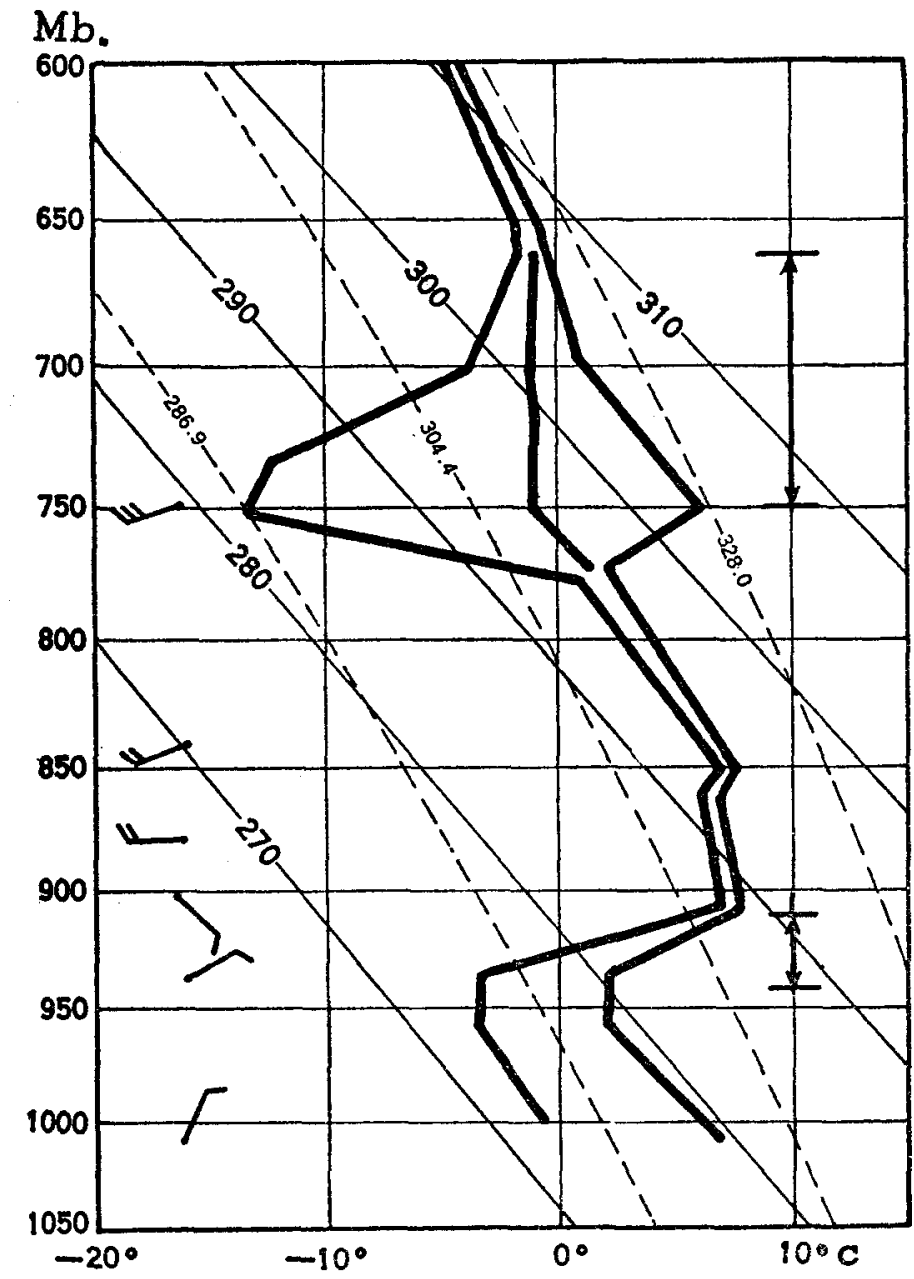

FIGURE 16.-A tmospheric sounding at Charleston, S. C., 2200 EST, December 12, 1947. Plotted heavy solid lines are temperature (right), potential pseudo-wet-bulb temperature (left), and wet-bulb temperature (center, between 770 and $660 \mathrm{mb}$.). Light solid lines are dry adiabats and light broken lines are pseudo-adiabats.

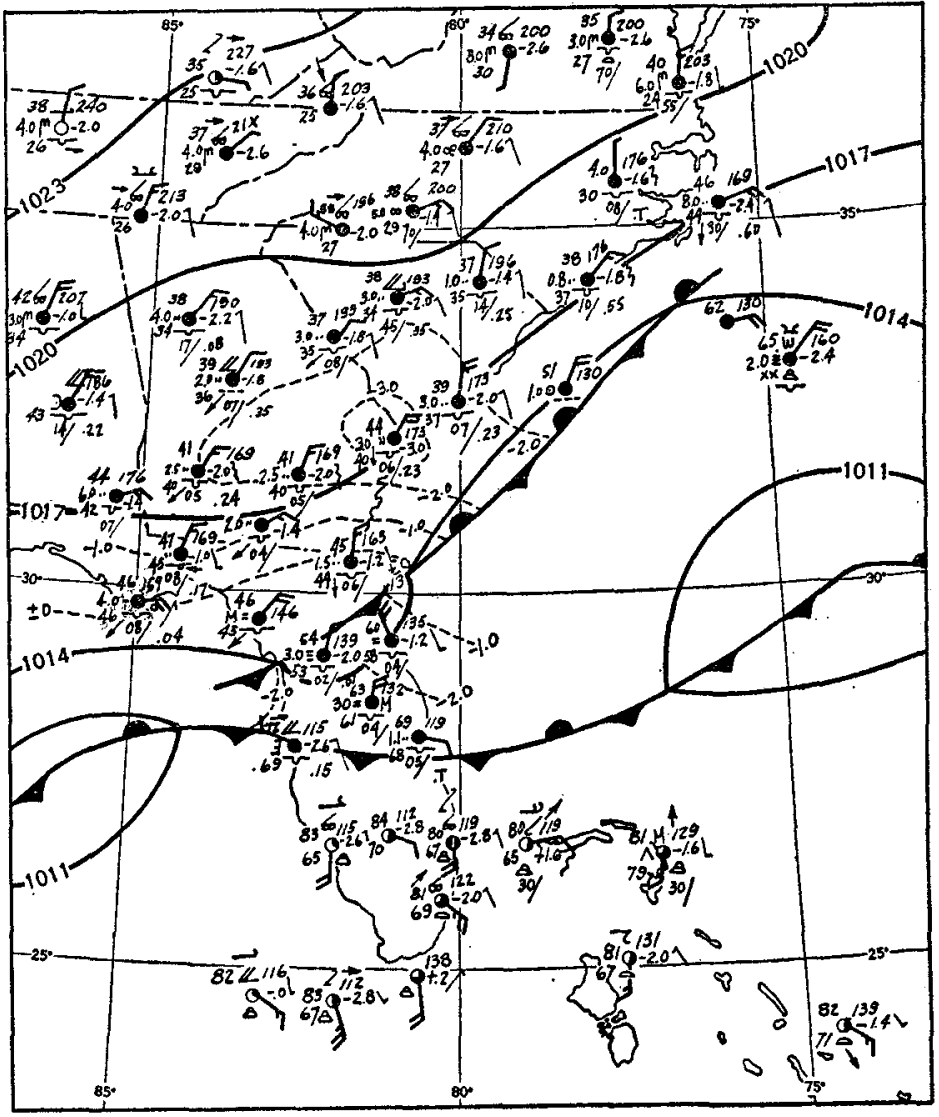

FIGURe 17.-Surface weather chart for 1330 EST, December 13, 1947.

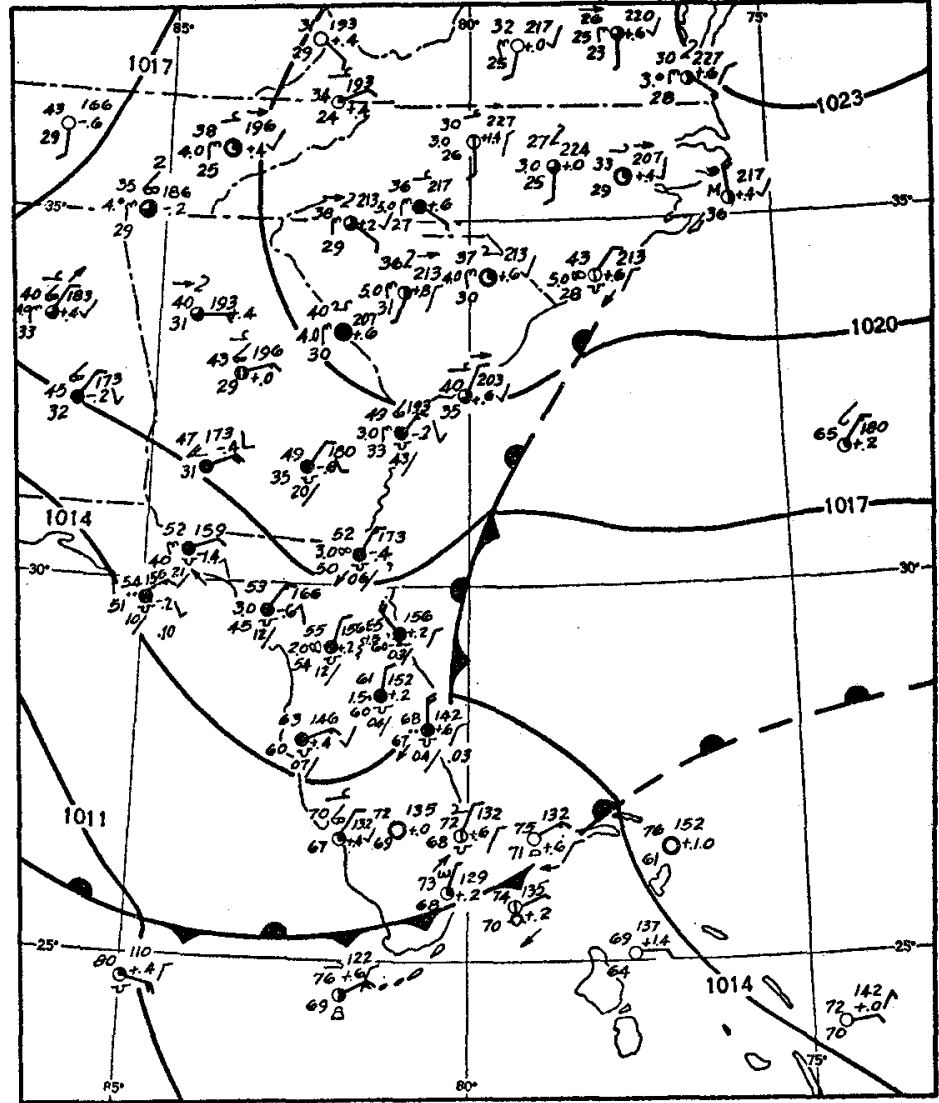

FIGURE 18.-Surface weather chart for 1930 EST, December 14, 1947. 


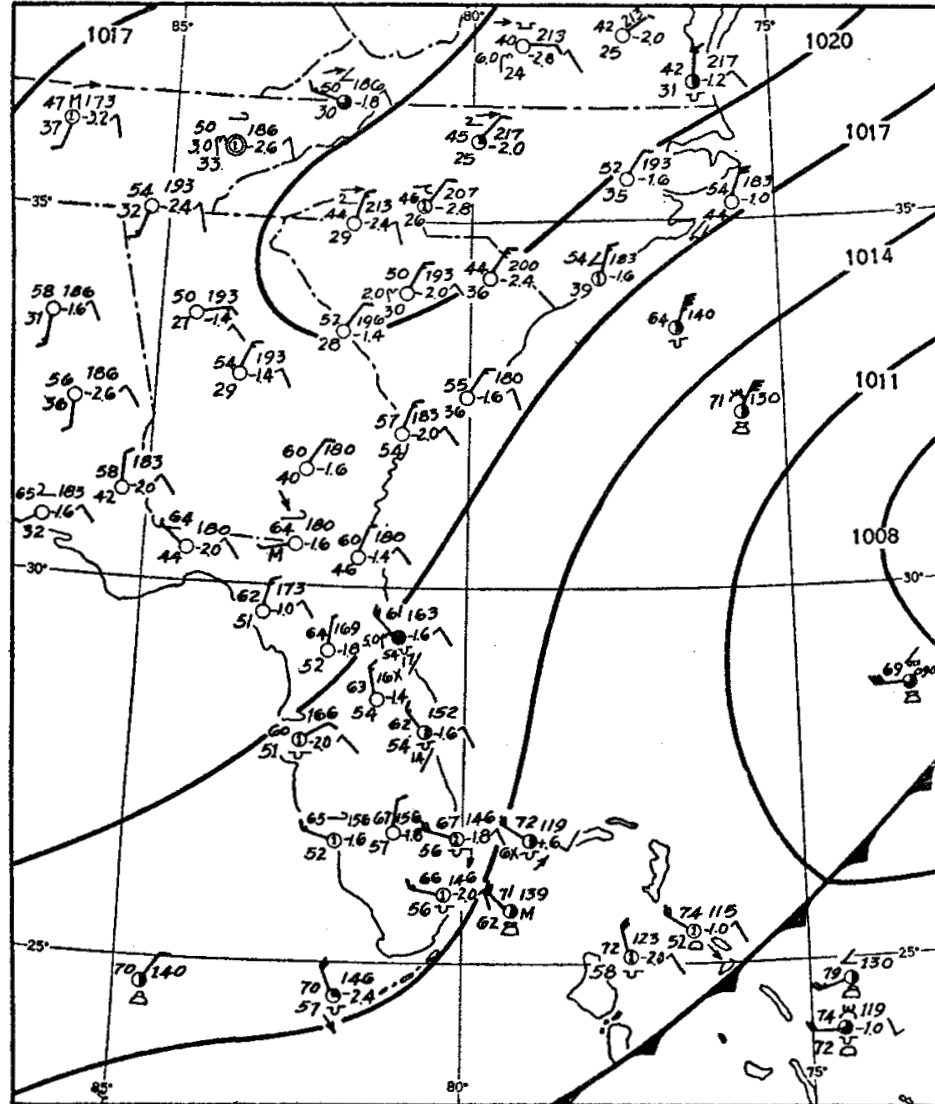

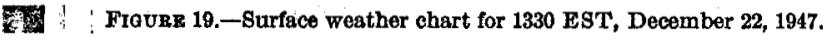

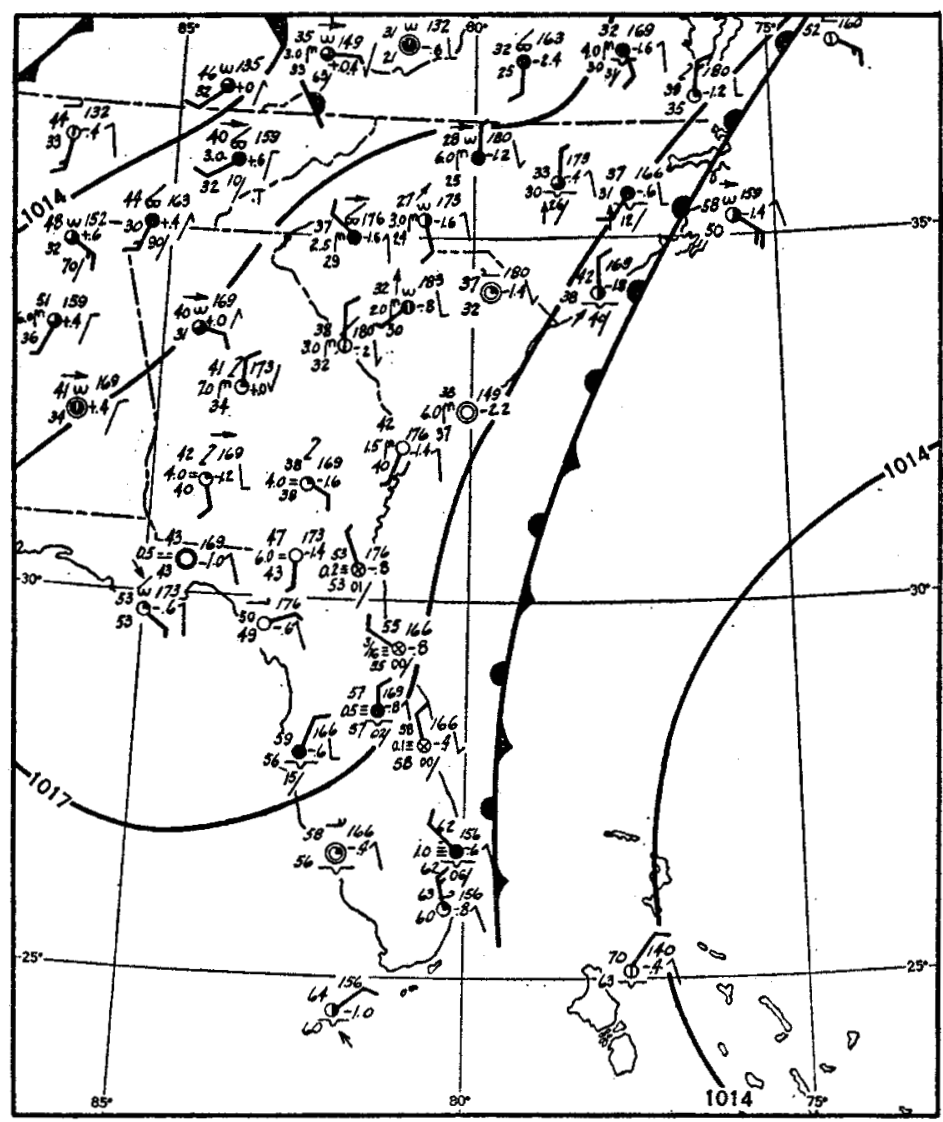

Figure 20.-Surface weather chart for 0130 EST, December 23, 1947.

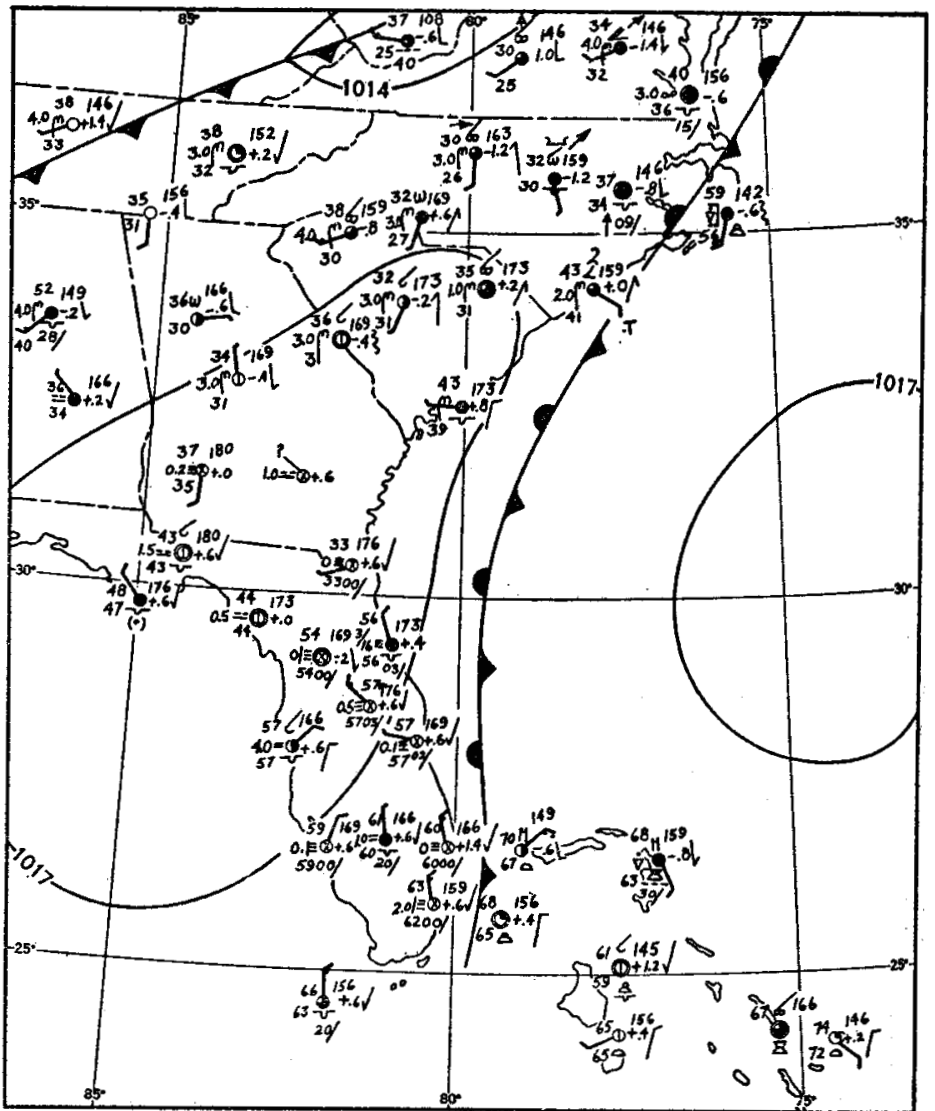

FIG URE 21.- Surface weather chart for 0730 EST, December 23, 1947.

\section{OTHER EXAMPLES}

Limitations of this article preclude the discussion of further examples. While it has been possible to present the facts in these three cases, the selective treatment may leave some doubt that the Gulf Stream front is altogether real and recurrent. Those who care to pursue the matter further may be interested in the following chart references:

1. Additional soundings which show, under similar conditions, two fronts aloft:

Charleston, S.C., December 11, 1947, 1100 EST Charleston, S.C., December 25, 1947, 1100 EST

Miami, Fla., December 25, 1947, 1100 EST

Tampa, Fla., January 20, 1948, 1100 EST

Tampa, Fla., January 25, 1948, 1100 EST

2. Another sounding indicating a front in the Gulf Stream off lower Florida, with polar stratus at 1,000 feet underrunning an easterly current 4,000 feet thick at Miami:

Miami, Fla., January 19, 1948, 1100 EST

3. Other winds aloft charts showing a front skirting the coast of the Carolinas:

2,000- and 4,000-foot levels for:

December 11, 1947, 2300 EST

January 25, 1948, 1700 EST

November 11, 1948, 2300 EST

November 12, 1948, 0500 EST 


\section{ACKNOWLEDGMENT}

The author is indebted to Mr. Phillip D. Thomas of the Miami Weather Bureau Airport Station for valuable aid in the preparation of this article.

\section{REFERENCES}

1. J. J. George, The Causes and Forecasting of Low Ceilings and Fogs at the Jacksonville Airport, Eastern Air Lines, Atlanta, Ga., 1939.

2. Frederick C. Fuglister, "Average Monthly Sea Surface
Temperatures of the Western North Atlantic Ocean," Papers in Physical Oceanography and Meteorology, vol. X, No. 2, Massachusetts Institute of Technology and Woods Hole Oceanographic Institution, May 1947.

3. John D. Watson, Formation and Dissipation of Northeast Transitional Stratus at Jacksonville, Fla. (unpublisbed research report, Weather Bureau Airport Station, Jacksonville, Fla., 1948).

4. James E. Miller, Cyclogenesis in the Altantic Coastal Region of the United States, College of Engineering, New York University, 1945. 